\title{
KEEPING MUD OFF THE BENCH: THE FIRST AMENDMENT AND REGULATION OF CANDIDATES' FALSE OR MISLEADING STATEMENTS IN JUDICIAL ELECTIONS
}

\author{
ADAM R. LONG \\ INTRODUCTION \\ In the last fifty years, perhaps no facet of American constitu- \\ tional democracy has changed more than campaigns for judicial of- \\ fice. Judicial elections long stood in sharp contrast to elections for ex- \\ ecutive, legislative, or administrative office. In keeping with the \\ judicial role of impartial adjudicator, judicial candidates historically \\ avoided political controversy and campaigned on "polite promises of \\ integrity." During the late twentieth century, judicial elections were \\ transformed from their more humble, less contentious beginnings into \\ elections virtually indistinguishable, in both financial scope and cam- \\ paign conduct, from other political campaigns. \\ Campaign donations and expenditures in judicial elections have \\ risen at exponential rates across the country. In the Los Angeles area, \\ campaign expenditures in the average superior court race increased \\ twenty-two fold from 1976 to $1994 .^{2}$ In 1980, a campaign for an Ohio \\ Supreme Court seat cost $\$ 100,000 ;^{3}$ in 2000 , a campaign for a seat on \\ the same court cost an estimated $\$ 9$ million. ${ }^{4}$ In Michigan, the cam- \\ Copyright (C) 2001 by Adam R. Long. \\ 1. William Glaberson, States Rein in Truth-Bending Court Races, N.Y. TimEs, Aug. 23, \\ 2000, at A1. \\ 2. Shelia Kaplan \& Zoë Davidson, The Buying of the Bench, NATion, Jan. 26, 1998, at 11, \\ 11. \\ 3. William Glaberson, Fierce Campaigns Signal a New Era for State Courts, N.Y. Times, \\ June 5, 2000, at A1. \\ 4. William Glaberson, States Take Steps to Rein in Excesses of Judicial Politicking, N.Y. \\ TIMES, June 15, 2001, at A1.
}


paigns for three Supreme Court seats in the 2000 election cost at least $\$ 16$ million each.

These rising costs fuel concerns that campaign contributors are seeking the best justice that money can buy. One national publication has noted that "an influx of money from the tobacco industry, casinos, insurance companies, doctors and businesses" finances many judicial campaigns. ${ }^{6}$ In her 2000 reelection bid, incumbent Justice Alice Robie Resnick of the Ohio Supreme Court received eighty-four percent of her total campaign contributions, totaling $\$ 329,175$, from Ohio trial lawyers. ${ }^{7}$ The other three candidates in the race for Resnick's Supreme Court seat received only $\$ 55,000$ combined from Ohio trial lawyers. ${ }^{8}$ In the late 1980 s, Texaco representatives made campaign contributions of $\$ 72,700$ to seven Texas Supreme Court justices while the appeal from the $\$ 11$ billion Pennzoil lawsuit against Texaco was pending before the court. ${ }^{9}$ Pennzoil's lawyers responded by contributing more than $\$ 315,000$ to justices on that same court. ${ }^{10}$ Most striking of all, a number of the justices who received campaign contributions from both Texaco and Pennzoil were not even facing reelection. $^{11}$

Not only have recent years witnessed an explosion of campaign expenditures and vast individual donations by parties hoping to influence judicial decisionmaking, but also the conduct of judicial candidates and supporters during campaigns has changed since the days of "polite promises of integrity." The influx of money has fueled an increase in political attack advertisements, which utilize the skills of political consultants to craft slickly packaged, memorable images of both candidates and opponents. In a 1984 race for the Louisiana Supreme Court, Justice John Dixon's opponent ran the following newspaper advertisement, accompanied by a drawing of a large dagger:

JOHN DIXON DOESN'T THINK 20 STAB WOUNDS ARE

ENOUGH .... On appeal to the Louisiana Supreme Court, six Jus-

\footnotetext{
5. Glaberson, supra note 4, at A1.

6. Kaplan \& Davidson, supra note 2, at 11; see also Shelia Kaplan \& Zoë Davidson, Dicey Justice, NATION, Jan. 26, 1998, at 15, 15 (reporting that, in 1996 and 1997, the casino industry in Nevada "poured more than $\$ 300,000$ into the state's judicial races").

7. Personal Injury Lawyers Bankroll Resnick's Re-election, PR NEWSWIRE, June 29, 2000.

8. Id.

9. James J. Alfini \& Terrence J. Brooks, Ethical Constraints on Judicial Election Campaigns: A Review and Critique of Canon 7, 77 KY. L.J. 671, 671 (1989).

10. Id.

11. $I d$.
} 
tices agreed with the death sentence. ONLY JOHN DIXON DIDN'T .... HE DIDN'T THINK MORE THAN 20 TIMES WAS ENOUGH TO JUSTIFY THE DEATH PENALTY. WHAT ABOUT YOU? THERE COMES A TIME TO DRAW THE LINE. THE TIME IS NOW. ${ }^{12}$

During the 2000 campaign, Citizens for a Strong Ohio, a pro-business organization, accused Justice Alice Robie Resnick of the Ohio Supreme Court "of having an anti-business bias, encouraged by the donations of trial lawyers." zens for a Strong Ohio sponsored, Justice Resnick was depicted "in black robes switching a vote after someone dumped bags of money on her desk. Another show[ed] a blindfolded lady justice peeking at a pile of money on her scales, before she and the scales fall over and break." ${ }^{14}$ Justice Resnick was not defenseless in her reelection campaign, however; Ohio unions, trial lawyers, and teachers' organizations each ran advertisements attacking her opponent, Judge Terrance O'Donnell. One pro-Resnick advertisement told voters that Judge O'Donnell "once ruled in favor of the employer in the case of a factory worker dismembered and killed by an unsafe machine."15

The explosion of campaign expenditures and the proliferation of attack advertisements demonstrate the dilemma facing the thirty-nine states that currently elect judges. ${ }^{16}$ States that elect judges grapple with "the conflict between the needs to preserve judicial neutrality and to maintain public respect for the legal system, and the political realities of election campaigns." ${ }^{17}$ That is, how should a judicial candidate campaign during a popular election? In the context of judicial elections, a state's interests in preserving judicial integrity and impar-

12. Max Minzner, Gagged but Not Bound: The Ineffectiveness of the Rules Governing Judicial Campaign Speech, 68 UMKC L. REV. 209, 209 (1999).

13. David Ruppe, Soft Money's Spread: Business Buys a Voice During Ohio Supreme Court Race, ABCNEWS.com, at http://abcnews.go.com/sections/politics/DailyNews/ohiosoftmoney_ 001103.html (last visited Nov. 5, 2000) (on file with the Duke Law Journal).

14. Id.

15. Spencer Hunt, Chief Justice: Appoint Judges; Moyer Distressed by Negative Ads, CinCINNATI ENQUiRer, Nov. 10, 2000, at C1.

16. See, e.g., Patrick M. McFadden, Electing Justice: The Law and Ethics of JUDiCIAL ELECTION CAMPAIGNS 9 (1990) (observing that "[o]nly eleven states and the District of Columbia have eschewed public elections entirely in their selection of appellate court judges and trial judges of general jurisdiction"); Glaberson, supra note 4, at A1 (stating that, in thirtynine states, "at least some judges face elections to get or keep their offices").

17. Elizabeth I. Kiovsky, Comment, First Amendment Rights of Attorneys and Judges in Election Campaigns, 47 OHIO ST. L.J. 201, 201 (1986). 
tiality and in a potential litigant's right to a fair and impartial judiciary can conflict with a candidate's right to free speech. These potentially conflicting interests and rights demonstrate the need for "compromises between political reality and the aim of maintaining the appearance of judicial impartiality." 18

In both the role it performs and the public image it seeks to maintain, the judiciary differs from the executive and legislative branches. Judges must administer the law objectively and independently, "serv[ing] as impartial arbiters beholden only to their duty to dispense justice." $"$ Popularly elected officeholders cannot serve on a purely impartial and independent basis and hope to remain in office. Because they are elected, executive officers and legislators must at all times consider their constituencies' views when performing the duties of office. ${ }^{20}$ An elected judiciary, however, must maintain not only judicial impartiality and independence, but also a level of public trust and confidence higher than that reserved for other political branches. If the citizenry sees judges as politicians first, concerned with reelection and the appeasement of campaign contributors in every decision they make, the public will question the validity and legitimacy of judicial decisions and, in fact, the judiciary as a whole. If the judiciary must both function differently and be perceived differently than the executive and legislative branches, then judicial candidates must campaign differently than executive and legislative candidates.

The campaign finance issue in judicial elections clearly poses a significant threat to the real and perceived integrity and impartiality of the judiciary. ${ }^{21}$ The public belief that judicial elections produce "[t]he best justice(s) money can buy" ${ }^{22}$ does not inspire trust and confidence in elected judiciaries, and many commentators have discussed the causes of, and possible solutions to, the influx of big money into

18. E. WAyne Thode, RePorter's Notes to Code of Judicial CONDUCT 96 (1973).

19. Neil K. Sethi, Comment, The Elusive Middle Ground: A Proposed Constitutional Speech Restriction for Judicial Selection, 145 U. PA. L. REV. 711, 714 (1997) (citing SARA Mathias, Electing Justice: A Handbook of Judicial Election ReForms 6 (1990)).

20. $I d$.

21. See generally Kathryn Abrams, Some Realism About Electoralism: Rethinking Judicial Campaign Finance, 72 S. CAL. L. REV. 505 (1999) (discussing the increasing problems associated with campaign finance in judicial elections); Paul D. Carrington, Judicial Independence and Democratic Accountability in Highest State Courts, 61 LAW \& ConTEMP. Probs. 79 (Summer 1998) (same); Erwin Chemerinsky, Preserving an Independent Judiciary: The Need for Contribution and Expenditure Limits in Judicial Elections, 74 CHI.-KENT L. REV. 133 (1998) (same).

22. Alfini \& Brooks, supra note 9, at 671 . 
once-modest state judicial campaigns. ${ }^{23}$ Although campaign finance poses a great threat to judicial impartiality and independence, judicial candidates' conduct further weakens the perceived integrity of judicial institutions. Attack advertisements and campaign misrepresentations erase what line remains between politician and judge, and such conduct has only recently received attention from public officials, academics, and the media. ${ }^{24}$ The citizenry cannot conceivably maintain faith in the judiciary's impartiality and integrity if it witnesses the slick, misleading advertisements and public mudslinging that candidates use to reach the bench every election year.

The growth of campaign expenditures and the use of thirtysecond television and radio advertisements have forced states to restrict candidates' knowing misrepresentations in campaign communications to preserve the perceived integrity of the judiciary. If judicial candidates knowingly misrepresent their opponents' records and positions in a culture that pays little attention to the substance of judicial campaigns, "[t]he dignity [of the judiciary] ... will go the way the confidence of the American public has gone with other branches of government populated by politicians." 25 Punishing judicial candidates for their knowing misrepresentations is one way to distinguish judicial candidates from other politicians, thereby preserving public faith in the judiciary.

For example, on July 21, 2000, the Alabama Judiciary Inquiry Commission (JIC) began disciplinary proceedings against Alabama Supreme Court Justice Harold F. See, Jr., for statements Justice See's campaign disseminated during the 2000 primary election for chief justice of the Alabama Supreme Court. ${ }^{26}$ During the primary campaign against Judge Roy S. Moore, Justice See's campaign ran advertisements that questioned Judge Moore's record, especially his leniency towards drug dealers. ${ }^{27}$ The JIC claimed that Justice See violated

23. See supra note 21 .

24. See, e.g., Glaberson, supra note 4, at A1 (describing the efforts made by "legislators, governors, courts, [and] citizens' groups" to address the "excesses of judicial politicking" in the wake of the 2000 election).

25. Jennifer L. Brunner, Comment, Separation of Power as a Basis for Restraint on a Free Speaking Judiciary and the Implementation of Canon 7 of the Code of Judicial Conduct in Ohio as a Model for Other States, 1999 DET. C. L. REV. 729, 748.

26. Butler v. Ala. Judicial Inquiry Comm'n, 111 F. Supp. 2d 1224, 1227 (M.D. Ala. 2000) [hereinafter Butler I]. Justice See lost in the primary election for chief justice and remained an associate justice of the Alabama Supreme Court after the election. Id. at 1226.

27. Id. at 1227; Glaberson, supra note 1, at A1. 
Canon $7 \mathrm{~B}(2)$ of the Alabama Canons of Judicial Ethics, which stated in relevant part:

[A] candidate shall not ... distribute false information concerning a judicial candidate or an opponent, either knowing the information to be false or with reckless disregard of whether that information is false; or ... distribute true information about a judicial candidate or an opponent that would be deceiving or misleading to a reasonable person. $^{28}$

After the disciplinary proceeding against him began, Justice See and others brought suit in the federal district court for the Middle District of Alabama, seeking an injunction against the JIC on the ground that Alabama's Canon $7 \mathrm{~B}(2)$ violated First Amendment rights of free speech. ${ }^{29}$ The district court granted Justice See's motion and enjoined enforcement of Canon $7 \mathrm{~B}(2)$ on the ground that the canon "is not narrowly drafted and . . . unnecessarily infringes upon... First Amendment rights., ${ }^{, 0}$ The district court in Butler v. Alabama Judicial Inquiry Commission (Butler I) relied heavily on In re Chmura, ${ }^{31}$ a 2000 Michigan Supreme Court decision that struck down Michigan's prohibition on judicial candidates' false or misleading communications for overbreadth and vagueness. ${ }^{32}$

The Eleventh Circuit, doubting the propriety of the district court's injunction against an ongoing state ethics proceeding, certified three questions to the Alabama Supreme Court concerning the procedural protections afforded Justice See in the proceedings. ${ }^{33}$ In response, the Alabama Supreme Court reversed an earlier position, cited the district court opinions and Chmura approvingly, and revised

28. Ala. Canons of Judicial Ethics Canon 7B(2) (effective Jan. 1, 1998). The Alabama Supreme Court previously had voted 8-1 to approve this Canon, with only Justice See dissenting. Butler v. Ala. Judicial Inquiry Comm'n, 245 F.3d 1257, 1260 (11th Cir. 2001) [hereinafter Butler III]. Canon 7B(2) was later modified by the Alabama Supreme Court in Butler v. Alabama Judicial Inquiry Commission, No. 1001119, 2001 WL 812624, at *8 (Ala. May 15, 2001) [hereinafter Butler IV]. For a discussion of the modifications to Canon 7B(2), see infra note 34 and accompanying text.

29. Butler I, $111 \mathrm{~F}$. Supp. 2d at 1225 (seeking a temporary restraining order); Butler v. Alabama Judicial Inquiry Comm'n, 111 F. Supp. 2d 1241, 1243 (M.D. Ala. 2000) [hereinafter Butler II] (seeking a preliminary injunction).

30. Butler I, 111 F. Supp. $2 \mathrm{~d}$ at 1233 . The court converted the temporary restraining order granted in Butler I into a preliminary injunction in Butler II on the same grounds given for the temporary restraining order. Butler II, $111 \mathrm{~F}$. Supp. 2d at 1254.

31. 608 N.W.2d 31 (Mich. 2000).

32. Id. at 38 .

33. Butler III, 245 F.3d at $1265-66$. 
Alabama Canon $7 \mathrm{~B}(2)$ to prohibit the dissemination of "demonstrably false information concerning a judicial candidate or an opponent "with "actual malice"- that is, with knowledge that it is false or with reckless disregard of whether it is false or not." ${ }^{34}$ In light of these changes, the Eleventh Circuit found that Justice See's First Amendment claims were moot, vacated the district court's preliminary injunction, and abstained from deciding Justice See's other claims in light of the ongoing JIC proceedings.

Although the Eleventh Circuit's final decision in the Butler litigation effectively ended the controversy over Alabama's regulation of false statements by judicial candidates, the fight over the constitutionality of similar restrictions in other states has just begun. The Butler case promises to be one of the first of many constitutional challenges in federal courts to state restrictions on misrepresentations by judicial candidates. Recent contentious judicial elections have increased the demand for regulation of candidates' conduct, ${ }^{36}$ and the creation of new restrictions and increased enforcement of existing regulations inevitably will bring more attention to the constitutional conflict over candidates' speech restrictions.

In this Note, I argue that restrictions on knowing misrepresentations, as set forth in Canon 5A(3)(d) of the American Bar Association's 1990 Model Code of Judicial Conduct, ${ }^{37}$ are both constitutional and of vital importance. Courts have long recognized that a state has a compelling interest in maintaining the integrity and impartiality of its judiciary. ${ }^{38}$ The judiciary's role and the state's interest in the integrity and impartiality of its judiciary necessitate a different approach to regulation of judicial elections. I demonstrate that restrictions on

34. Butler IV, No. 1001119, 2001 WL 812624, at *8 (Ala. May 15, 2001) (quoting New York Times Co. v. Sullivan, 376 U.S. 254, 280 (1964)).

35. Butler v. Ala. Judicial Inquiry Comm'n, 261 F.3d 1154, 1157-60 (11th Cir. 2001) [hereinafter Butler $V]$.

36. See, e.g., Glaberson, supra note 4, at A1 (noting that "[i]n more than a dozen states in recent months, legislators, governors, courts or citizens' groups have begun efforts to limit the role of campaign politics in the selection of state judges").

37. Canon 5A(3)(d) of the American Bar Association's 1990 Model Code of Judicial Conduct is broader in scope than the new Canon $7 \mathrm{~B}(2)$ that the Alabama Supreme Court created in the Butler litigation. See supra note 34 and accompanying text.

38. See, e.g., Landmark Communications, Inc. v. Virginia, 435 U.S. 829, 848 (1978) (Stewart, J., concurring) ("There could hardly be a higher governmental interest than a State's interest in the quality of its judiciary."); Stretton v. Disciplinary Bd., 944 F.2d 137, 142 (3d Cir. 1991) ("There can be no question ... that a state has a compelling interest in the integrity of its judiciary."). 
knowingly false and misleading statements by judicial candidates can be tailored narrowly to achieve the state's interest and to fit within current First Amendment jurisprudence, including the "actual malice" defamation standard for public figures set forth by the Supreme Court in New York Times Co. v. Sullivan ${ }^{39}$ and its progeny.

In Part I, I discuss the history of state regulation of judicial campaign conduct. Specifically, I examine the evolution of the American Bar Association's Code of Judicial Conduct. Part II examines the constitutional challenges to the 1972 and 1990 Codes' "gag rule"-the provisions restricting speech on "disputed legal or political issues"and the First Amendment arguments made for and against the gag rule. Most challenges to the constitutionality of judicial campaign speech restrictions have involved the gag rule. Although the gag rule presents different issues than the knowing misrepresentation provision, certain arguments concerning the gag rule provide insight into the relatively new misrepresentation controversy.

In Part III, I examine the constitutionality of state regulation of judicial candidates' misrepresentations. I focus on the New York Times Co. v. Sullivan line of cases, which sets forth the standard to be used when scrutinizing state restrictions on defamatory statements about public figures. I also discuss the brief history of First Amendment attacks on state regulation of judicial candidates' misrepresentations. Part IV attempts to determine how, in light of the gag rule's experience, the New York Times defamation standard, and current misrepresentation jurisprudence, a state may construct a constitutional misrepresentation provision that is broader and more effective than the simple prohibition of knowingly or recklessly false statements put forth by the Alabama Supreme Court in the Butler litigation. Finally, I demonstrate why the 1990 Code's misrepresentation clause provides one example of a provision sufficiently narrow in scope and well-defined to be constitutionally valid.

\section{THE HISTORY OF RESTRICTIONS ON JUDICIAL CAMPAIGN CONDUCT: THE ABA MODEL CODE OF JUDICIAL ETHICS}

After completing its Canons of Professional Ethics for Lawyers in $1908,{ }^{40}$ the American Bar Association (ABA) began formulating

39. 376 U.S. 254 (1964).

40. CANONS OF Professional Ethics FOR LAWYERS (1908); Randall T. Shepard, Campaign Speech: Restraint and Liberty in Judicial Ethics, 9 GEO. J. LEGAL ETHICS 1056, 1063 (1996). 
the first American code of judicial conduct. ${ }^{41}$ The ABA created a Committee on Judicial Ethics, chaired by Chief Justice William Howard Taft, to address the matter. ${ }^{42}$ The Taft Committee produced the Canons of Judicial Ethics, ${ }^{43}$ which were formally adopted at the ABA annual meeting of $1924 .^{44}$ Designed to protect parties' rights to impartial adjudication, ${ }^{45}$ the Taft Committee's final product consisted of thirty-four canons, "rang[ing] from ... specific prohibitions on judicial work, such as ex parte communications, to more general aspirational statements about avoiding the appearance of impropriety, limiting business and charitable activities, and restraining judicial electioneering. ${ }^{46}$ With respect to candidates for judicial office, the new canons directed that candidates for the bench should refrain from "campaign promises":

[a] candidate for judicial position should not make or suffer others to make for him, promises of conduct in office which appeal to the cupidity or prejudices of the appointing or electing power; he should not announce in advance his conclusions of law on disputed issues to secure class support, and he should do nothing while a candidate to create the impression that if chosen, he will administer his office with bias, partiality or improper discrimination. ${ }^{47}$

Reaction to the new canons was generally positive. ${ }^{48}$ The ABA called the new Code of Judicial Ethics "'the outstanding feature of the meeting." ${ }^{49}$ In response to the perceived restrictive nature of the

41. See Minzner, supra note 12, at 212; Shepard, supra note 40, at 1063; Amy Craig, Comment, The Burial of an Impartial Judicial System: The Lifting of Restrictions on Judicial Candidate Speech in North Carolina, 33 WAKE Forest L. REV. 413, 417 (1998). Although the American Bar Association's efforts, which eventually led to the 1924 Canon of Judicial Ethics, discussed infra, was the first formal attempt at creating an American code of judicial conduct, the tradition of holding judges to defined ethical standards dates back thousands of years. Moses instructed the Israelite judges: "Thou shalt not wrest judgment; thou shalt not respect persons, neither take a gift; for a gift doth blind the eyes of the wise, and pervert the words of the righteous." Deuteronomy 16:19 (King James). By the seventh century, penalties for judicial partiality began to appear in European kingdoms. Shepard, supra note 40, at 1061.

42. Shepard, supra note 40, at 1063.

43. CANONS OF JUdiCial ETHICS (1924); Shepard, supra note 40, at 1063.

44. Forty-Seventh Annual Meeting Maintains Association's High Standard, 10 A.B.A. J. 555,555 (1924).

45. Minzner, supra note 12 , at 212.

46. Shepard, supra note 40, at 1063-64 (citations omitted).

47. Canons of Judicial Ethics Canon 30 (1924).

48. Minzner, supra note 12, at 212; Shepard, supra note 40, at 1064.

49. Shepard, supra note 40, at 1063 n.17 (quoting Forty-Seventh Annual Meeting Maintains Association's High Standard, supra note 44). 
regulations, the Columbus Dispatch noted at the time, "“[t]here is plenty of room off the judicial bench for anyone who regards [these] standard[s] as too seriously restrictive of individual freedom." ${ }^{,{ }^{5}}$ The concept that judges should be held to formal standards of conduct gained overwhelming acceptance from both the bar and the general public, as demonstrated by the fact that, "[s]ince 1960, nearly every state . . . creat[ed] a judicial disciplinary body ... empowered to pursue disciplinary complaints and to recommend a variety of sanctions to the highest court of the state."

The primary problems that eventually arose from the 1924 Canons were not directly caused by the restrictions on judicial conduct but rather by the vagueness of the canons' ethical directives. In 1972, the ABA promulgated the Model Code of Judicial Conduct, ${ }^{52}$ consisting of seven canons, in an attempt "to shift the Canons from a list of moral exhortations to a particular guide of conduct." ${ }^{, 53}$ To make clear that the new code went beyond simple moral aspirations, the preface to the 1972 Code stated that the "canons and text establish[ed] mandatory standards unless otherwise indicated." ${ }^{, 4}$ The 1972 Code addressed candidates' communications in judicial elections in Canon $7 \mathrm{~B}(1)(\mathrm{c})$, which stated that a candidate for judicial office "should not make pledges or promises of conduct in office other than the faithful and impartial performance of the duties of the office; announce his views on disputed legal or political issues; or misrepresent his identity, qualifications, present position, or other fact." ${ }^{, 55}$ Between 1972 and 1990, forty-seven states, the District of Columbia, and the Federal Judicial Conference adopted some form of the 1972 Code. $^{56}$

The ABA again revisited the issue of judicial ethics in 1990 and adopted a new Model Code of Judicial Conduct. ${ }^{57}$ In the preamble, the ABA announced that the 1990 Code was designed to ensure that "judges, individually and collectively, ... respect and honor the judicial office as a public trust and strive to enhance and maintain confi-

50. Press Comments on Proposed Code of Judicial Ethics, 9 A.B.A. J. 191, 191 (1923) (quoting the Columbus Dispatch).

51. Shepard, supra note 40, at 1065.

52. Model Code of Judicial Conduct (1972).

53. Minzner, supra note 12, at 213.

54. Preface to Model Code of Judicial Conduct (1972).

55. Id. Canon $7 \mathrm{~B}(1)(\mathrm{c})$.

56. JefFrey M. Shaman ET Al., Judicial CONDUCt AND ETHics 3 n.19 (3d ed. 2000) (providing a complete list of states codifying all or large parts of the 1972 Code).

57. Model Code of Judicial Conduct (1990). 
dence in our legal system. ${ }^{, 58}$ The revisions made to the restrictions on judicial candidates' conduct "were substantial, and ... heavily discussed." " After a number of state and federal courts found Canon $7 \mathrm{~B}(1)(\mathrm{c})$ of the 1972 Code to be unconstitutionally vague and overbroad, ${ }^{60}$ the ABA worked to construct narrow, constitutionally valid restrictions on campaign conduct by candidates for judicial office. Canon 5A(3)(d) of the 1990 Code, replacing the old Canon 7B(1)(c), states in relevant part:

A candidate for judicial office ... shall not (i) make pledges or promises of conduct in office other than the faithful and impartial performance of the duties of the office; (ii) make statements that commit or appear to commit the candidate with respect to cases, controversies or issues that are likely to come before the court; or (iii) knowingly misrepresent the identity, qualifications, present position or other fact concerning the candidate or an opponent .... ${ }^{61}$

Canon 7B(1)(c)'s "pledges and promises" clause was left intact, but the 1990 Code replaced the former "announce" clause with a less expansive "likely to come before the court" provision. ${ }^{62}$ Also, no mention is made of "disputed legal or political issues" in the 1990 version. ${ }^{63}$ The 1990 Code also contained a significantly modified "misrepresentations" clause, adding a knowledge requirement and specifying that the restriction applied to statements made regarding a candidate's opponent as well as the candidate herself. The revised code also replaced "should not" with "shall not" in a number of sections, including Canon $5 \mathrm{~A}(3)(\mathrm{d})$, to emphasize the mandatory nature of the provisions. ${ }^{64}$ By 2000 , twenty states had adopted all or large portions of the 1990 Code, including two previous non-code states, Rhode Island and Wisconsin. ${ }^{65}$

58. Id. pmbl. at 3 .

59. Minzner, supra note 12 , at 214.

60. For a discussion of cases striking down 1972 Canon 7B(1)(c) as unconstitutional, see infra Part II.A.

61. Model Code of Judicial Conduct Canon 5A(3)(d) (1990).

62. Craig, supra note 41, at 418.

63. Id.

64. Shepard, supra note 40, at 1066 .

65. SHAMAN ET AL., supra note 56, at $3 \mathrm{n} .20$ (providing a complete list of states codifying all or large parts of the 1990 Code). Also, a number of additional states have adopted a combination of the two codes or modified their codes based on the 1972 Code to reflect the changes made in the 1990 version. $I d$. at 4-5. 


\section{The CONSTITUTIONALITY OF THE GAG RulE AND ITS RELEVANCE TO THE MisREPRESENTATION ClAUSE}

\section{A. First Amendment Challenges to the Gag Rule}

Challenges to the constitutionality of Canon $7 \mathrm{~B}(1)(\mathrm{c})$ appeared soon after states began adopting the 1972 Code in whole or in large part as a means to regulate judicial candidates' conduct. The majority of these challenges addressed the gag rule, the restrictions on "pledges or promises of conduct in office," or "announce[ments] [of the candidate's] views on disputed legal or political issues." ${ }^{, 66}$ In 1984, the Southern District of Ohio was the scene of the first federal challenge to the gag rule in Berger v. Supreme Court. ${ }^{67}$ In Berger, the plaintiff-candidate wanted to promise during the campaign to make divorce litigants appear without an attorney and enter mediation, and to be more personally involved in the administration and resolution of cases. ${ }^{68}$ Believing that such statements would violate Canon $7 \mathrm{~B}(1)(\mathrm{c})$, Berger sought a preliminary injunction enjoining enforcement of the canon. ${ }^{69}$ The court denied the injunction request because it found that Berger's promises were not in violation of Canon $7 \mathrm{~B}(1)$ (c) as they "relate[d] to the faithful performance of the duties of judicial office." ${ }^{, 0}$ Even though it found that Berger's comments would not violate the canon, the court in Berger addressed the overall constitutionality of the restrictions. After finding that Canon $7 \mathrm{~B}(1)(\mathrm{c})$ is a content-based restriction on speech, ${ }^{71}$ the Berger court applied a strict scrutiny standard and held that the canon was necessary to achieve a compelling state interest. ${ }^{72}$ Four years later, the Sixth Circuit affirmed the district court's decision in Berger and upheld the constitutionality of Canon $7 \mathrm{~B}(1)(\mathrm{c})$ on the same grounds. ${ }^{73}$

The district court in Berger held that a state "has a compelling interest in assuring ... that judicial campaigns are run in a manner so as

\footnotetext{
66. Model Code of Judicial Conduct Canon 7B(1)(c) (1972).

67. 598 F. Supp. 69 (S.D. Ohio 1984) [hereinafter Berger I].

68. Id. at 72 .

69. Id.

70. Id. at 75 .

71. Id. at $74-75$.

72. Id. at 75 .

73. Berger v. Supreme Court, 861 F.2d 719, No. 87-3935, slip op. at 2-4 (6th Cir. Oct. 31, 1988) [hereinafter Berger II]. The Court's unpublished decision is referenced in a "Table of Decisions Without Reported Opinions" appearing in the Federal Reporter.
} 
not to damage the actual and perceived integrity of state judges and the bar." ${ }^{74}$ Most courts that later examined the gag rule's constitutionality accepted that the actual and perceived integrity and impartiality of the judiciary is a compelling state interest. ${ }^{75}$ The question then turned to the second part of the strict scrutiny analysis, whether the restriction on campaign communications by judicial candidates was narrowly tailored to protect the state's compelling interest without unduly impairing First Amendment rights. ${ }^{76}$

The next federal court to examine the gag rule struck down part of Canon 7B(1)(c)'s gag rule for failing the "narrowly tailored" aspect of the strict scrutiny standard. In ACLU v. Florida Bar, another preemptive strike case, a federal district court in Florida permanently enjoined enforcement of the "disputed legal and political issues" clause on overbreadth and vagueness grounds. ${ }^{78}$ The Florida Bar court accepted that "states need not treat candidates for judicial office the same as candidates for other elective offices" ${ }^{\text {"79 }}$ and that the state "has a compelling interest in protecting the integrity of the judiciary." tive means available to protect the state's compelling interest, however, finding that Canon $7 \mathrm{~B}(1)(\mathrm{c})$ 's broad language effectively prohibited "announcements on almost every issue that might be of interest to the public and the candidates in a judicial race." ${ }^{, 81}$

The decisions concerning Canon 7B(1)(c) that followed Berger and Florida Bar reiterated many of the arguments presented in those two cases and followed the inconsistent pattern that the first two federal courts addressing the gag rule established. The supreme courts of Washington $^{82}$ and Kentucky ${ }^{83}$ upheld the gag rule under constitutional

74. Berger I, 598 F. Supp. at 75.

75. For an exception to this general statement, see infra note 92 and accompanying text. But cf. Brown v. Hartlage, 456 U.S. 45, 52 (1982) (noting that the states have a legitimate interest in preserving the integrity of their electoral processes).

76. See Brown, 456 U.S. at 53-54 ("When a State seeks to restrict directly the offer of ideas by a candidate to the voters, the First Amendment surely requires that the restriction be demonstrably supported by not only a legitimate state interest, but a compelling one, and that the restriction operate without unnecessarily circumscribing protected expression.").

77. 744 F. Supp. 1094 (N.D. Fla. 1990).

78. Id. at 1099 .

79. Id. at 1097.

80. Id. at 1098 .

81. Id.

82. In re Kaiser, 759 P.2d 392 (Wash. 1988).

83. Deters v. Judicial Ret. \& Removal Comm'n, 873 S.W.2d 200 (Ky. 1994). 
attack. In In re Kaiser, the Washington Supreme Court found that Canon $7 \mathrm{~B}(1)(\mathrm{c})$ was necessary and sufficiently limited to ensure the protection of the state's compelling interest in maintaining the integrity of and public confidence in the judiciary. ${ }^{84}$ The Kentucky Supreme Court in Deters v. Judicial Retirement and Removal Commission upheld the 1990 Code's version of the gag rule after having earlier struck down the 1972 Code's version. ${ }^{85}$ The court in Deters relied on Ackerson v. Kentucky Judicial Retirement \& Removal Commission ${ }^{86}$ in which a federal district court found Kentucky's canon, based on the 1990 Code's gag rule, sufficiently narrow to avoid any unconstitutional abridgement of First Amendment rights. ${ }^{87}$

In Beshear v. Butt, ${ }^{88}$ another federal district court struck down all of Canon $7 \mathrm{~B}(1)(\mathrm{c})$ on overbreadth and vagueness grounds. ${ }^{89}$ In this "rare case in which a constitutional challenge arose as a defense to actual disciplinary proceedings," $" 90$ a candidate for municipal court judge faced sanctions for stating during the election that his court would not accept plea bargaining. ${ }^{91}$ The court struck down Canon 7B(1)(c) after finding that the state presented no compelling interest and failed to demonstrate "some imminent dangers or wrong growing out of Judge Beshear's expressions."

84. Kaiser, 759 P.2d at 399.

85. Deters, 873 S.W.2d at 204-05; see also J.C.J.D. v. R.J.C.R., 803 S.W.2d 953, 954-57 (Ky. 1991) (holding that the 1972 Code's gag rule violated the First Amendment).

86. 776 F. Supp. 309 (W.D. Ky. 1991).

87. Id. at 315. The Ackerson court enjoined enforcement of the canon as it applied to comments about administrative issues surrounding the court but upheld the restrictions on adjudicatory matters. Id. at 315-16.

88. 773 F. Supp. 1229 (E.D. Ark. 1991), rev'd without op., 966 F.2d 1458 (8th Cir. 1992).

89. Id. at 1234 .

90. Mark R. Riccardi, Code of Judicial Conduct Canon 7B(1)(c): An Unconstitutional Restriction on Freedom of Speech, 7 GEO. J. LEGAL ETHICS 153, 173 (1993).

91. Beshear, 773 F. Supp. at 1233.

92. Id. at 1234. One observer noted that the Arkansas Judicial Discipline and Disability Commission refused to hear Beshear's constitutional argument against the canon, which may have led to the court's "unusually strict review." See Riccardi, supra note 90, at 174 ("Where a state agency refuses to entertain constitutional defenses when the First Amendment is implicated, it strongly suggests that the statute is too broadly worded and, depending on the exact nature of the contested speech, too broadly applied as well."). The court's use of a hybrid "imminent danger or wrong" test instead of standard strict scrutiny has led a few commentators to criticize the Beshear decision. See, e.g., Daniel J. Burke, Code of Judicial Conduct Canon 7B(1)(c): Toward the Proper Regulation of Judicial Speech, 7 GEO. J. LEGAL ETHICS 181, 193 (1993) (arguing that the Beshear decision is fatally flawed because the court "referr[ed] to the wrong clause in the canon and employ[ed] the wrong constitutional test"). 
Not surprisingly, the federal circuit courts of appeals are currently in conflict over the constitutionality of the 1972 Code's gag rule. As noted earlier, the Sixth Circuit upheld the 1972 version of the gag rule in the Berger litigation. ${ }^{93}$ In Stretton v. Disciplinary Board ${ }^{94}$ the Third Circuit overturned a district court decision striking down Canon $7 \mathrm{~B}(1)(\mathrm{c})$, requiring that the state supreme court construe the Canon narrowly, assuring its constitutionality. ${ }^{95}$ The court applied the two-part strict scrutiny standard and found that the state had a compelling interest in protecting the integrity of its judiciary and that, when narrowly construed by the state supreme court, the gag rule was the least restrictive means available. ${ }^{96}$ Defending its reluctance to overturn Canon $7 \mathrm{~B}(1)(\mathrm{c})$ and assuming that the state supreme court would construe the restriction narrowly, the Third Circuit in Stretton relied on the rule the Supreme Court gave in Edward J. DeBartolo Corp. v. Florida Gulf Coast Building \& Construction Trades Council ${ }^{97}$ concerning statutory construction in the face of constitutional challenge. ${ }^{98}$ DeBartolo Corp. stated that "“every reasonable construction must be resorted to, in order to save a statute from unconstitutionality.","99

Two years after Stretton, the Seventh Circuit struck down all of Canon 7B(1)(c) as unconstitutionally overbroad and vague in Buckley v. Illinois Judicial Inquiry Board. ${ }^{100}$ Judge Posner, writing for the Seventh Circuit in Buckley, found the prohibition on any announcement of views on "disputed legal or political issues" unconstitutionally vague and overbroad because virtually anything could be a disputed political issue. ${ }^{101}$ Posner recognized the inherent conflict between the First Amendment rights of candidates for public office and the state's interest in having judges decide cases according to law rather than campaign promises. Because of the breadth and vagueness of the statute, Posner found that silence presented "the only safe response"

\footnotetext{
93. See supra note 73 and accompanying text.

94. 944 F.2d 137 (3d Cir. 1991).

95. Id. at 138 .

96. Id. at $142-44$.

97. 485 U.S. 568 (1988).

98. Stretton, 944 F.2d at 144.

99. Id. (quoting DeBartolo Corp., 485 U.S. at 575).

100. 997 F.2d 224, 228 (7th Cir. 1993).

101. Id. The 1990 Codes addressed and rectified this problem by eliminating the words "political or legal" from the Canon and adding the phrase "likely to come before the court." See Model Code of Judicial Conduct Canon 5A(3)(d)(ii) (1990).
} 
for a candidate. ${ }^{102}$ Posner used economic analysis to describe the need for an unfettered "marketplace of ideas" existing before an election:

[I]nterference with the marketplace of ideas and opinions is at its zenith when the "customers" are most avid for the market's "product." The only time the public takes much interest in the ideas and opinions of judges or judicial candidates is when an important judicial office has to be filled; and in Illinois those offices are filled by election. It is basically only during the campaign that judicial aspirants have an audience, and literal compliance with [the Rule] would deprive the audience of the show. ${ }^{103}$

Starting with Berger and Florida Bar, state and federal courts that have examined the 1972 Code's gag rule remain in conflict over the provision's constitutionality.

\section{B. Arguments Regarding the Gag Rule and the First Amendment and Their Applicability to the Misrepresentation Clause}

The constitutionality of restrictions on judicial candidates' right to pledge or promise conduct in office or to discuss disputed legal or political issues remains contested. At the root of the controversy stand three long-recognized interests: a state's interest in the integrity and impartiality of its judiciary, a candidate's right to free speech, and the voter's interest in access to relevant information concerning candidates. Much jurisprudence and debate in the last twenty years focused on how courts and lawmakers can balance these three interests to satisfy both the concerned parties and the Constitution. ${ }^{104}$

Some arguments about the gag rule in both case law and the academic literature are directly applicable when examining the constitutionality of restrictions on knowing misrepresentation by judicial candidates. ${ }^{105}$ These arguments demonstrate that, in an analysis of the

\footnotetext{
102. Buckley, 997 F.2d at 228.

103. Id. at 228-29.

104. See, e.g., id. at 227 :

[O]nly a fanatic would suppose that one of the principles should give way completely to the other - that the principle of freedom of speech should be held to entitle a candidate for judicial office to promise to vote for one side or another in a particular case or class of cases or that the principle of impartial legal justice should be held to prevent a candidate for such office from furnishing any information or opinion to the electorate beyond his name, rank, and serial number.
}

105. Because the gag rule and misrepresentation clause restrict different types of speech, not all arguments concerning the gag rule are relevant when discussing restrictions on knowing misrepresentations. One interesting rationale presented to support restrictions on speech by judicial candidates is that, under the separation of powers doctrine, "political issues are not justici- 
constitutionality of the misrepresentation clause, the state's interest in the integrity of the judiciary remains constant. The voter's interest in information, however, shifts to support restrictions on false or misleading statements so long as the restrictions are narrowly tailored and clearly defined, thus defined to avoid a "chilling" effect on candidates' communication of accurate information to voters.

In advocating the gag rule's constitutionality, a number of scholars argue that the Code is necessary to protect future unknown litigants, as well as the interests of candidates, voters, and the state. Arguing that the canons are ineffective at prohibiting discussion of potential issues before the court, Max Minzner criticizes most courts that have examined the constitutionality of the gag rule for "fail[ing] to recognize that the goal of the Canon is to protect the right to a fair trial." ${ }^{106}$ Randall Shepard believes that restraints on campaign speech by judicial candidates are actually due process protections for future litigants that will appear before elected judges, giving a constitutional source to the state's (and future litigant's) interest in preserving the impartiality of the judiciary. ${ }^{107}$

However, with both the gag rule and misrepresentation clause, the state's interest is the preservation of the integrity and impartiality of, and public confidence in, its judiciary. Judicial impartiality is not directly jeopardized by candidates making false or misleading statements. But the integrity of the judiciary and the citizenry's perception of and faith in the judicial branch are even greater concerns with respect to judicial candidates' dishonest statements. As judicial elections evolve to resemble elections for political offices, complete with enormous war chests and mudslinging, the threat to judicial integrity and public confidence in the judiciary posed by knowingly false statements or misrepresentations by judicial candidates becomes increasingly real. A state's interest in protecting the integrity of its judi-

able ... [m]aking promises or airing predispositions on issues or cases likely to come before a court is, in effect, unofficial and prohibited policy making." Brunner, supra note 25, at 733-34. Obviously, because false or misleading statements do not constitute policymaking, this argument would not apply to a misrepresentation provision.

106. Minzner, supra note 12, at 228; see also Burke, supra note 92, at 183 ("Canon 7B(1)(c) is a necessary restriction fundamental for the continued protection of the right to a fair trial.").

107. Shepard, supra note 40, at 1060. Shepard, chief justice of the Indiana Supreme Court, discusses the conflict between a candidate's interest in free speech and the litigant's interest in due process, believing that, because both interests are weighty, the choice is a policy decision that should be, and has been, made by the state legislatures. Id. ("[L]egislative and rule-making institutions have already made a legitimate choice that should be honored by judges."). 
ciary is equally strong with respect to the gag rule and misrepresentation clause.

The courts that struck down the constitutionality of various versions of the gag rule all stressed both the importance of a candidate's free speech rights and the voter's interest in information about candidates. Those two interests work much differently in the context of restrictions on false and misleading communications. As described by Judge Posner in Buckley, the voter needs a complete and uninhibited "marketplace of ideas" to make an informed decision when voting, especially in the context of judicial office, which rarely receives much attention outside of elections. ${ }^{108}$ False and misleading statements that a candidate knowingly makes only clutter and distort this marketplace of ideas, making it harder for a voter to make the informed decision that the free marketplace should promote.

Continuing with the "marketplace of ideas" concept, a restriction on misrepresentation might inhibit the flow of valuable ideas and information before an election if the prohibition is overly broad or unclear. A chilling of candidates' speech would leave the voter with less information about those candidates who were uncertain about what, if anything, they could say during a campaign. This is the problem Posner identified as the source of the gag rule's unconstitutionality in Buckley. ${ }^{109}$ The problem of overbreadth or vagueness must be avoided if misrepresentation restrictions are to be constitutionally valid. The Supreme Court has stated that the First Amendment does not protect false statements. ${ }^{110}$ Therefore, the only interests a candidate would have in a misrepresentation provision is that it be narrowly tailored and well defined to prevent any chilling of protected speech. So long as a misrepresentation clause clears the narrow construction hurdle, protecting against overbreadth and vagueness, its constitutionality should be assured.

108. See supra note 103 and accompanying text.

109. See supra notes 101-02 and accompanying text.

110. Milkovich v. Lorain Journal Co., 497 U.S. 1, 18 (1990). 


\section{THE CONSTITUTIONALITY OF STATE RESTRICTIONS ON MISREPRESENTATIONS BY JUDICIAL CANDIDATES}

\section{A. State Regulation of Defamation Concerning Public Figures}

The preceding analysis of the arguments about the gag rule's constitutionality provides valuable insight into the constitutionality of misrepresentation restrictions but does not end the issue. The $\mathrm{Su}$ preme Court, in a line of cases starting with New York Times Co. v. Sullivan, ${ }^{111}$ has defined the extent to which a state may regulate statements made about public figures with respect to their official conduct in light of the First Amendment. Although these cases specifically involve civil defamation claims made by aggrieved public figures, the standards the Court announced also would apply to penalties enforced directly by the state with respect to statements of a libelous or slanderous nature. ${ }^{112}$ The creation of a civil claim for defamation and restrictions on judicial candidates' false or misleading statements have the same effect on the speaker, forbidding the articulation of false statements. Also, the language used in the decisions, discussing "free debate" and the appropriateness of criticism of public officials, helps expand the applicability of this line of cases to speech restrictions on judicial candidates. Any restriction on false or misleading statements by judicial candidates must conform to the standards set by the Court in the New York Times line of cases.

In New York Times, a county commissioner for the city of Montgomery, Alabama, brought a civil libel action against the New York Times Company based on an advertisement that the paper carried describing the status of civil rights in Montgomery. ${ }^{113}$ The Court devised an "actual malice" test to determine when a defamation claim based on criticism of a public official infringes upon the speaker's First Amendment rights or unduly chills protected speech. ${ }^{114}$ The decision "prohibit[ed] a public official from recovering damages for a defama-

111. 376 U.S. 254 (1964).

112. The Alabama Supreme Court recognized the applicability of the New York Times line of cases when they incorporated the decision's "actual malice" standard into their revised Canon 7B(2) after Justice See's successful challenge to the canon's constitutionality. See supra note 34 and accompanying text. In Part IV, I will argue that Canon 5A(3)(D)(iii) of the 1990 Model Code, a broader and more effective restriction on misrepresentations by judicial candidates than the rule put forth by the Alabama Supreme Court, is constitutional under the New York Times line of cases.

113. 376 U.S. at 256 .

114. Id. at $279-80$. 
tory falsehood relating to his official conduct unless he proves that the statement was made with 'actual malice'-that is, with knowledge that it was false or with reckless disregard of whether it was false."115 The New York Times Court justified the high standard for defamation claims against public officials by pointing to the importance of open exchange, which is guaranteed by the First Amendment. Justice Brennan, writing for the majority, believed that an "erroneous statement is inevitable in free debate, and ... it must be protected if the freedoms of expression are to have the 'breathing space' that they 'need ... to survive." "116 In his concurrence, Justice Goldberg expressed his strong belief "that the Constitution accords citizens ... an unconditional freedom to criticize official conduct."117

In Curtis Publishing Co. v. Butts, ${ }^{118}$ decided three years after New York Times, the Court considered whether the New York Times actual malice standard applied to defamation claims made by public figures who do not hold official public office. ${ }^{119}$ In Butts, the Saturday Evening Post accused Butts of "conspiring to 'fix' a football game between the University of Georgia and the University of Alabama," causing Butts to initiate a libel claim against the Post's publishers. ${ }^{120}$ At the time of the suit, Butts was the athletic director at the University of Georgia and its former football coach. Although Georgia is a state university, Butts technically was employed by the Georgia Athletic Association, a private corporation, raising the question of whether a privately employed individual could be a "public official" under New York Times. ${ }^{121}$

The Butts Court settled the issue by expanding the coverage of the New York Times actual malice defamation standard to include "public figures" in addition to public officials. ${ }^{122}$ In his concurring opinion, Chief Justice Warren defined "public figures" as nonpublic persons who "are nevertheless intimately involved in the resolution of important public questions or, by reason of their fame, shape events in areas of concern to society at large. " ${ }^{, 23}$ Under the broad definition

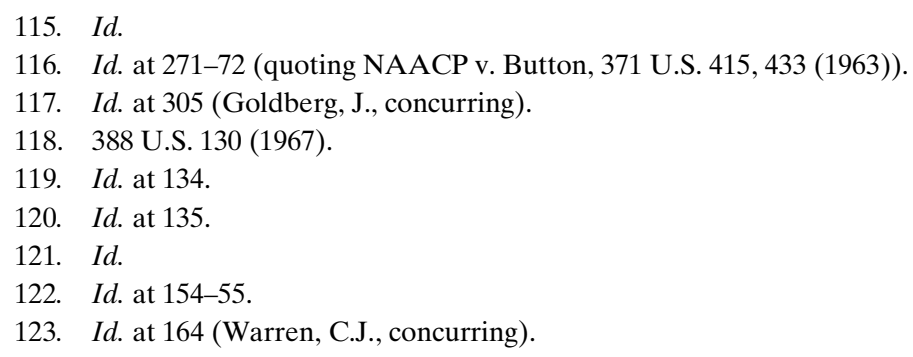


given by Chief Justice Warren in Butts, candidates for judicial office certainly would fall within the category of public figures when one considers their "involve[ment] in the resolution of important public questions." ${ }^{24}$ Therefore, under Butts, the New York Times actual malice standard is relevant to any restriction on misrepresentations that affect judicial candidates, whether challengers or incumbent judges.

In Gertz v. Robert Welch, Inc. ${ }^{125}$ and Milkovich v. Lorain Journal Co. ${ }^{126}$ the Supreme Court further clarified the scope of the actual malice test. In Gertz, the Court held that the standard introduced in New York Times applies only to public persons, stating that private individuals seeking redress for defamation need not show actual malice. ${ }^{127}$ The Court based this distinction on two grounds. First, "public officials and public figures have voluntarily exposed themselves to increased risk of injury from defamatory falsehood concerning them. No such assumption is justified with respect to a private individual." ${ }^{128}$ Second, public persons "usually enjoy significantly greater access to the channels of effective communication and hence have a more realistic opportunity to counteract false statements." ${ }^{129}$ In Milkovich, the Court emphasized that First Amendment protections do not adhere to statements that imply facts falsely. ${ }^{130}$ The Court examined the distinctions between fact and opinion and held that "opinions" can be actionable consistent with the First Amendment "where a statement of 'opinion' on a matter of public concern reasonably implies false and defamatory facts regarding public figures or officials.",

\section{B. Constitutionality of the Misrepresentation Clause}

The vast majority of cases examining the constitutionality of state restrictions on judicial candidates' speech have concerned the gag rule. Yet, courts at both the state and local levels have tested a number of versions of the misrepresentation clause. An examination of these few cases, combined with the arguments presented concerning

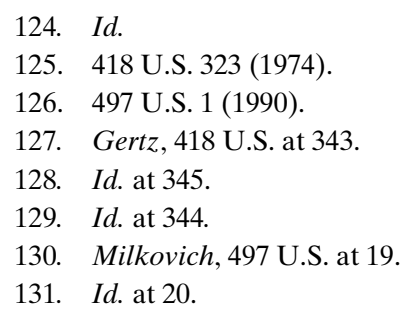


the gag rule's constitutionality and the New York Times line of cases, demonstrates how a state may restrict misrepresentations made by judicial candidates in hopes of maintaining the integrity of, and public confidence in, its judiciary.

In 1975, the Kansas Supreme Court was asked to determine the constitutionality of the recently created misrepresentation clause in Canon 7B(1)(c) of the 1972 Code. In In re Baker, ${ }^{132}$ the Kansas Supreme Court upheld sanctions leveled against a candidate under the misrepresentation clause for distributing literature that incorrectly stated that his opponent, the incumbent, could collect a monthly pension if he lost the election. ${ }^{133}$ Although the 1972 Code, unlike the 1990 Code, does not provide an explicit restriction on misrepresentations about a candidate's opponent, the court found that the phrase "other fact" brought a candidate's opponent within the language of the canon. ${ }^{134}$ The Baker court never discussed a First Amendment problem with the misrepresentation clause, noting that "[s]o long as we continue to have partisan elections for judicial office we think a challenger must be free to criticize an incumbent's record, so long as the criticism is accurate." ${ }^{, 135}$

In 1978, the Washington Supreme Court more closely examined the interplay of the 1972 Code's misrepresentation clause and the First Amendment in In re Donohoe. ${ }^{136}$ Again, the 1972 misrepresentation clause withstood constitutional attack. The court rejected a reprimanded attorney's free speech claims and upheld disciplinary action for his engaging in "an intentional and deliberate pattern of making false statements of fact." 137 The court found that Canon $7 \mathrm{~B}(1)(\mathrm{a})$, which states that a candidate for judicial office should maintain the dignity appropriate to judicial office, is not violated by a candidate's criticism of an opponent so long as the criticism is fair and factual. ${ }^{138}$ Echoing the language used in Baker, the court held that "[a] candi-

132. 542 P.2d 701 (Kan. 1975).

133. Id. at 706. The pension under Kansas statute would be available to the incumbent judge only if he were "permanently" disabled, which he was not. Id.

134. See id. at 706 ("Judge Baker and his supporters did 'misrepresent' a 'fact' in violation of Canon 7B(1)(c).").

135. Id. The Baker court actually overturned five of the six sanctions based on alleged violations of the gag rule but upheld the sanction for misrepresentation without a discussion of the clause's constitutionality. Id. at 703-07.

136. 580 P.2d 1093 (Wash. 1978).

137. Id. at 1097 .

138. Id. The same "dignity" language appears in the 1990 Code. MODEL CODE OF JUDICIAL CONDUCT Canon 5A(3)(a) (1990). 
date for judicial office has a right to challenge an incumbent judge's ability, decisions and judicial conduct, but it must be done fairly, accurately and upon facts, not false representations." ${ }^{\text {"139 }}$ With respect to free speech protections, the Donohoe court stated:

[W]e do not believe that the First Amendment protects one who utters a statement with knowledge of its falsity, even in the context of a judicial campaign. Such speech is not beneficial to the public and is generally harmful to the person against whom it is directed. The only beneficiary of the comment is the utterer thereof. On balance, such statements are not deserving of constitutional protection. ${ }^{140}$

After finding that Donohoe deliberately made false statements of fact, the court expressly noted that, because it determined that the statements at issue were false, it did not need to determine whether merely misleading statements are protected under the First Amendment. $^{141}$

In an unpublished 1997 decision, the Sixth Circuit upheld two provisions of the Ohio Code of Judicial Conduct similar to misrepresentation restrictions. In Harper v. Office of Disciplinary Counsel, ${ }^{142}$ Sara P. Harper, a sitting Ohio Court of Appeals judge, ran against an incumbent for a seat on the Ohio Supreme Court. ${ }^{143}$ During the campaign, Harper ran radio advertisements claiming the incumbent, Justice Alice Robie Resnick, was beholden to plaintiffs' lawyers who

\footnotetext{
139. Donohoe, 580 P.2d at 1097.

140. Id.

141. Id. at 1098. Candidates in a variety of states have been warned or disciplined for violating the misrepresentation clause. A judicial candidate in Michigan was "instructed that he could not use the slogan 'A Judge for a Change' because it falsely suggested that he was an incumbent judge.” Alfini \& Brooks, supra note 9, at 693-94 (citing State Bar of Mich. Comm. on Prof'l and Judicial Ethics, Informal Op. CI-556 (1980)). A judge in Kentucky "was suspended without salary for ten days for a violation of Canon $7 \mathrm{~B}(1)(\mathrm{c})$ after publishing campaign advertising that indicated a professional poll placed him ahead of his opponent when in fact no such poll had been conducted." Id. at 694 (citing In re Jack D. Wood, Unreported Order (Ky. Comm'n 1982)). Another judicial candidate in Kentucky was sanctioned for distributing campaign materials that falsely claimed that he was the incumbent. Id. at 693 (citing Order of Private Reprimand, 7 Accent on Courts, No. 1, at 23 (Ky. Comm'n 1985)). A judge in Washington state was publicly reprimanded "for a violation of Canon $7 \mathrm{~B}(1)(\mathrm{c})$ after issuing a campaign pamphlet, deceptively similar to the official voter's pamphlet, that failed to reveal that he had opposition and that the position sought was contested." Id. at 694 (citing In re McGlothen, Unreported Letter of Admonishment (Wash. Judicial Qual. Comm'n 1983)).

142. 113 F.3d 1234, No. 96-3186, 1997 WL 225899 (6th Cir. May 2, 1997) (unreported decision).

143. Id. at *1.
} 
gave more than $\$ 300,000$ to her campaign. ${ }^{144}$ The Ohio Supreme Court's Office of Disciplinary Counsel submitted a formal complaint against Harper, charging Harper with violation of Ohio's "Canon 2A, for failing to conduct herself so as to promote public confidence in the integrity and impartiality of the judiciary ... and Canon $7 \mathrm{~B}(1)(\mathrm{a})$, for failing to maintain the dignity appropriate to judicial office." ${ }^{145}$ Harper filed suit in federal court to enjoin disciplinary proceedings against her. ${ }^{146}$ Harper claimed that the two provisions of the Ohio Code violated her First Amendment right of free speech because of their unconstitutional overbreadth and vagueness, arguing that "these canons 'generally require that a judge must conduct herself in a manner that makes the judiciary look good' and prohibit not only false statements but also truthful statements that portray Ohio's judiciary in a negative light." ${ }^{147}$

The Sixth Circuit dismissed Harper's overbreadth and vagueness claims. Citing Stretton, the court held that "overbreadth may be avoided if the rule ... in question is reasonably susceptible of a narrow construction or has, in fact, been narrowly interpreted by the agency responsible for its enforcement." ${ }^{148}$ Echoing both Baker and Donohoe, the court found that "the [Ohio] supreme court has long held that a candidate for judicial office may criticize the judgments and conduct of the incumbent during an election campaign, but has emphasized that the criticism must be made in a fair and truthful manner." "With respect to the vagueness claim, which challenged the language "maintain the dignity" of judicial office and "promote public confidence" in the judiciary, the court cited the Supreme Court's decision in Parker v. Levy, ${ }^{150}$ in which the Court upheld the military's prohibition on conduct "unbecoming an officer and a gentleman." As in Parker, the court found that the disciplinary board had provided guidance for what "is and is not appropriate under the Code." ${ }^{, 152}$ According to the Sixth Circuit, Ohio sufficiently established that it

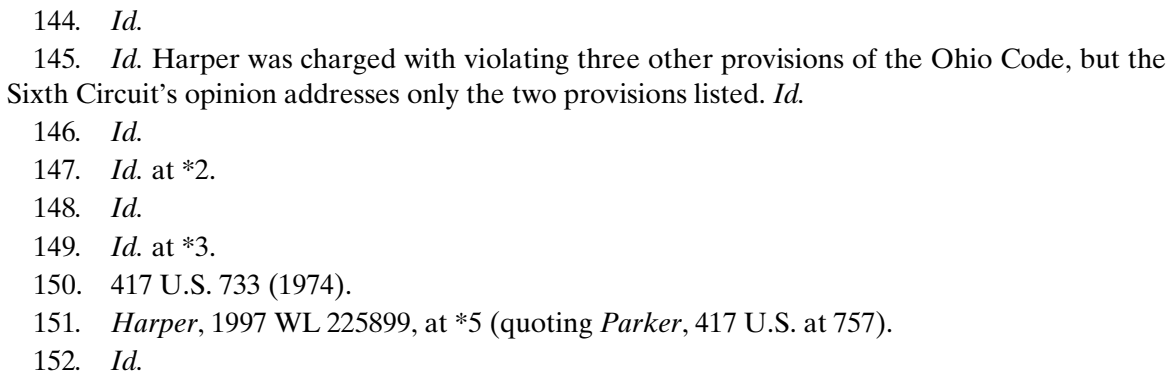


allows criticism of an incumbent judge or justice so long as "the criticism is truthful and accurate," which the court found sufficient to defeat a vagueness claim. ${ }^{153}$

Despite the extremely deferential approach the Sixth Circuit took in Harper with respect to state regulation of misrepresentations by judicial candidates, a federal district court in 2000 found a more narrowly worded provision unconstitutionally vague and overbroad in Butler v. Alabama Judicial Inquiry Commission (Butler I).$^{154}$ In Butler, the canon in question contained prohibitions on both the knowing or reckless dissemination of false information about the candidate or an opponent and the dissemination of true information that is deceptive or misleading to a reasonable person. ${ }^{155}$ Using a strict scrutiny standard for a content-based restriction on speech, the court in Butler held that, although the state has a compelling interest in maintaining the integrity of its judiciary, Canon $7 \mathrm{~B}(2)$ was not sufficiently narrowly tailored to satisfy the First Amendment. ${ }^{156}$

\section{CANON 5A(3)(D)(III) OF THE 1990 MODEL CODE OF JUDICIAL CONDUCT: A CONSTITUTIONAL RESTRICTION ON KNOWING MISREPRESENTATIONS BY JUDICIAL CANDIDATES}

After Butler, one might wonder whether judicial attempts to determine the constitutionality of the misrepresentation provisions of the 1972 and 1990 Codes will become as inconsistent and unclear as the constitutional validity of the gag rule. Under Berger II and Harper, it is clear that the Sixth Circuit, deferring to the state's interest in preserving judicial integrity, would uphold the more precise and narrow language used in the 1972 and 1990 Codes that prohibits misrepresentations by judicial candidates. The Third Circuit also would likely find the misrepresentation clause valid, considering the emphasis it placed on the narrow application, as opposed to construction, of

153. Id.

154. 111 F. Supp. 2d 1224, 1235 (M.D. Ala. 2000). For a discussion of the facts underlying the Butler decision, see supra notes 26-35 and accompanying text.

155. Ala. Canons of Judicial Ethics Canon 7B(2) (effective Jan. 1, 1998). As noted, the Alabama Supreme Court modified the requirements of Canon 7B(2) in Butler IV, No. 1001119, 2001 WL 812624, at *8 (Ala. May 15, 2001). See supra notes 28, 34 and accompanying text.

156. Butler I, 111 F. Supp. $2 \mathrm{~d}$ at 1233 . After the Alabama Supreme Court acknowledged that Canon $7 \mathrm{~B}(2)$ violated the First Amendment, and the court changed the canon's language to prohibit only the knowing or reckless dissemination of false information by judicial candidates, the Eleventh Circuit vacated the district court's decision on mootness grounds. Butler V, 261 F.3d 1154, 1157-60 (11th Cir. 2001). 
the gag rule in Stretton v. Disciplinary Board. The Seventh Circuit's concern with the gag rule's overbreadth and vagueness and its resulting chilling of protected speech, however, was exactly the same concern the federal district court in Butler and the Michigan Supreme Court in In re Chmura ${ }^{157}$ expressed with the versions of the misrepresentation clause they struck down. The task becomes, then, to find a way to structure a restriction on candidate misrepresentations that would be constitutionally acceptable, enforceable, and effective. The 1990 Code's misrepresentation clause presents one model that should survive First Amendment challenges.

For the statute in question to survive a First Amendment strict scrutiny analysis, the state must show, first, that the "regulation is necessary to serve a compelling state interest," and that the regulation "is narrowly drawn to achieve that end." 158 Virtually all courts agree that the preservation of judicial integrity is a compelling state interest. ${ }^{159}$ A state's attempt to prevent judicial candidates from making false or misleading statements during a campaign clearly represents an attempt to preserve the integrity of and public confidence in its judicial system. ${ }^{160}$ With the first part of a strict scrutiny analysis addressed, the question remains whether a misrepresentation provision can be narrowly drawn to avoid unnecessary infringement upon First Amendment rights.

Reflecting concerns with the gag rule, the courts that have struck down various versions of the misrepresentation clause have done so on overbreadth and vagueness grounds, finding that the clauses were not narrowly tailored to achieve the state's compelling interest, and that they also unduly restricted protected speech. The 1990 Code solves the overbreadth problems that plagued earlier versions of the misrepresentation provisions. Because it applies only to knowing misrepresentations, the 1990 Code's misrepresentation clause contains an intent element that protects a speaker's benign, but erroneous, misrepresentations during a campaign. The court in Butler approvingly cited the Harper decision from the Sixth Circuit but held that Alabama's version of the misrepresentation clause was unconstitutionally

157. 608 N.W.2d 31 (Mich. 2000).

158. Perry Educ. Ass'n v. Perry Local Educators' Ass'n, 460 U.S. 37, 45 (1983).

159. Even the courts in Butler and Chmura, when striking down misrepresentation provisions, found the state's interest in the integrity of the judiciary to be compelling and satisfactory for strict scrutiny analysis. Butler I, 111 F. Supp. 2d at 1233; Chmura, 608 N.W.2d at 40.

160. See supra note 25 and accompanying text. 
overbroad because it lacked the "knowing" requirement that Ohio's misrepresentation clause contained in Harper. ${ }^{161}$ The Butler I court even stated that it could "conceive of no way, without rewriting the canon, to limit the construction and narrow the canon's proscriptions." 162 Had Alabama's canon at issue in Butler I and Butler II contained the language of Ohio's code or the 1990 Model Code, the court almost certainly would have reached a different conclusion.

A prohibition only on knowing misrepresentations also presents fewer vagueness concerns than earlier versions of the clause. The two elements of a violation are clearly defined and can be shown with some degree of certainty. A state can go even further than the 1990 Model Code by providing a list of acceptable and unacceptable actions in the actual canon. The Sixth Circuit in Harper upheld the constitutionality of a loosely worded restriction on judicial candidates' speech because it believed that the state supreme court had sufficiently defined the meaning of the Canon's vague language. ${ }^{163}$ A state could use examples to define precisely the type of the conduct that constitutes "knowing misrepresentations" to better instruct judicial candidates and avoid vagueness concerns. ${ }^{164}$

The "knowing misrepresentation" language used in Canon 5A(3)(d)(iii) of the 1990 Code conforms to the actual malice standard developed by the Court in the New York Times line of cases. Under the actual malice standard, a state cannot allow recovery of damages by a public official for defamation relating to his official conduct unless the speaker acted with knowledge that the statement was false or with reckless disregard of the statement's accuracy. ${ }^{165}$ The 1990 Code prohibits knowingly false statements and therefore fits safely within the knowledge requirement of the actual malice standard. The Alabama Supreme Court in the Butler litigation went so far as to equate the actual malice standard with the state's revised misrepresentation clause, which bans only recklessly and knowingly false statements

\footnotetext{
161. Butler I, 111 F. Supp. 2d at 1236-38.

162. Id. at 1238 .

163. Harper v. Office of Disciplinary Counsel, 113 F.3d 1234, No. 96-3186, 1997 WL 225899, at $* 2-* 6$ (6th Cir. May 2, 1997). For a discussion of the Harper decision, see supra notes $142-53$ and accompanying text.

164. For example, a state could require explicitly in its code that in print, radio, or television advertisements, distortions of an opponent's judicial record fall within the purview of the regulations.

165. New York Times Co. v. Sullivan, 376 U.S. 254, 279-80 (1964).
} 
made by judicial candidates. ${ }^{166}$ Of course, by prohibiting only knowingly false statements, the Alabama Supreme Court left unregulated knowingly misleading statements, leaving the efficacy of their new restrictions in doubt.

The question remains whether knowingly misleading statements, which most courts have found fall within the scope of a restriction on misrepresentation, satisfy an actual malice analysis in the context of judicial elections. Although the Alabama Supreme Court in the Butler litigation did not prohibit knowingly misleading statements in Alabama's revised Canon 7B(2), prohibitions on knowingly misleading statements likely satisfy the New York Times standard for three reasons. First, in Milkovich v. Lorain Journal Co. ${ }^{167}$ the Court examined a state defamation law and held that First Amendment protections do not adhere to statements that imply false facts. ${ }^{168}$ The Court found that even statements made in the form of an opinion about the official work of public figures could be actionable for defamation if the opinion implies a false factual basis. ${ }^{169}$ In the context of knowing misrepresentations, a candidate-speaker is stating a fact, such as "Judge Doe let a convicted rapist walk free." Although this statement may be technically true, suppose that the actual cause of the rapist's release was a procedural error by a prosecutor, leaving the judge no choice but to release the rapist. In this situation, the statement knowingly and deceptively implies untrue facts, such as "Judge Doe does not think it is very important to imprison convicted rapists." Misrepresentations of this sort contain the implied, false factual foundation that the Milkovich Court found unprotected by the First Amendment. Because these statements lack First Amendment protections, the knowingly misleading category of restrictions is constitutional if narrowly tailored to avoid the infringement of legitimate First Amendment rights. As noted above, the knowledge requirement and use of examples of prohibited conduct would protect the regulations from overbreadth and vagueness challenges. ${ }^{170}$

Also, a rationale given for the public figure/private individual distinction in Gertz v. Robert Welch, Inc. ${ }^{171}$ suggests that state regula-

\footnotetext{
166. Butler IV, No. 1001119, 2001 WL 812624, at *8 (Ala. May 15, 2001) (quoting New York Times, 376 U.S. at 280).

167. 497 U.S. 1 (1990).

168. Id. at $18-19$.

169. Id. at 20-21.

170. See supra notes 161-64 and accompanying text.

171. 418 U.S. 323 (1974).
} 
tion of judicial candidates' knowingly misleading, though not technically false, statements is constitutional. In Gertz, the Court noted that public figures "usually enjoy significantly greater access to the channels of effective communication and hence have a more realistic opportunity to counteract false statements." ever, are more restricted in their ability to counteract false statements than typical public figures because their conduct is governed by Canon 5A(3)(d) of the 1990 Code, including the gag rule. ${ }^{173}$ As one state supreme court justice observed, "the target of false accusations in a race for the bench cannot fully respond to them .... [because most states have] rules that bar judicial candidates from discussing how they would vote on issues that might come before them."174 If Candidate A, running for a state supreme court seat, asserts, "If elected, Candidate B will invalidate all state gun control laws after finding they violate the Second Amendment," Candidate B may not be able to respond without violating the gag rule and taking a position on an issue "likely to come before the court." Judicial candidates cannot always use "channels of effective communication" to rebut misleading statements made about them and should not be left in the vulnerable position of fighting a political battle with one hand tied behind their backs.

Finally, the separate possibility exists that should it reject the first two arguments, the Court could carve out a small exception to the New York Times actual malice requirement for knowingly misleading statements, given the respect courts consistently and deservingly have paid to a state's interest in the protection of its judicial system's integrity. The New York Times standard represents a balance between the First Amendment protections for individuals and a state's interest in protecting public figures from defamatory statements. If the fact that the public figures in question are judicial candidates is thrown into the equation, it is entirely plausible that the courts, which always have recognized the preservation of judicial integrity as a compelling interest, would be willing to tilt the balance a bit in the state's favor. This additional weight thrown on the balance of interests may be enough to justify a narrow exception to New York

172. Id. at 344.

173. Model Code of Judicial Conduct Canon 5A(3)(e) (1990) ("A candidate for judicial office ... may respond to personal attacks or attacks on the candidate's record as long as the response does not violate Section 5A(3)(d).").

174. Glaberson, supra note 1, at A1 (paraphrasing Justice Leah J. Sears of the Georgia Supreme Court). 
Times. The Third Circuit, as demonstrated by Stretton, ${ }^{175}$ and the Sixth Circuit, as shown by Harper ${ }^{176}$ are two courts likely to accept such an exception if the states narrowly apply the restriction. This exception would be more universally recognized if the restriction on knowingly misleading statements is clearly defined and clarified with a list of examples of acceptable and unacceptable behavior. ${ }^{177}$ Examples add to a restriction's clarity and provide protection against constitutional attack on vagueness or chilling grounds.

\section{CONCLUSION}

With judicial campaigns receiving more funding and more attention, states that elect judges must ensure that judicial elections do not become indistinguishable from elections for other political offices. Judges play a unique role in government as impartial and unbiased arbiters of justice. Deceptive or false statements made by candidates during elections only cloud the public's knowledge of the candidates and weaken the perception of the judiciary as an institution of integrity and justice. Canon 5A(3)(d)(iii) of the 1990 Model Code of Judicial Conduct provides one model that states can constitutionally follow to preserve judicial integrity without abridging the free speech rights of candidates or limiting the flow of accurate information to voters. By requiring knowledge of a statement's inaccuracy, the provision excludes well-meaning but simply erroneous statements and guarantees that protected speech will not be chilled. Canon $5 \mathrm{~A}(3)(\mathrm{d})(\mathrm{iii})$ is a modest restriction, limited in scope, and many observers may argue that more needs to be done to protect the judiciary from those who seek to join it. Nevertheless, Canon 5A(3)(d)(iii) is sufficiently narrow to survive First Amendment attacks and represents a positive first step in defending the actual and perceived integrity of the judiciary.

175. See supra notes 94-99 and accompanying text.

176. See supra notes $142-53$ and accompanying text.

177. See supra note 164 and accompanying text. 